\title{
Effectiveness of a Selective Advising Program in Reducing the Degree of Compulsive Buying Behavior among Umm Al-Qura Female Students
}

\author{
Sawzan S. Basyouni ${ }^{1}$ \\ ${ }^{1}$ College of Education, Umm al-Qura University, Saudi Arabia \\ Correspondence: Sawzan S. Basyouni, College of Education, Umm al-Qura University, Saudi Arabia. E-mail: \\ sawzanbasyouni@yahoo.com
}

Received: August 8, 2017

Accepted: September 18, 2017

Online Published: December 29, 2017

doi:10.5539/ies.v11n1p127

URL: https://doi.org/10.5539/ies.v11n1p127

\begin{abstract}
The present study is an attempt to investigate the effectiveness of a selective advising program in reducing the degree of Compulsive Buying Behavior among female students, Faculty of Education at Umm al-Qura University. The sample consisted of (200) female students to verify the validity and reliability of the tool. The quasi-experimental method was utilized through two groups (experimental and control). The results indicated high rates of compulsive buying among the participants (18-30) years, where there was a great difference between the items of the scale and a great desire for buying for many reasons. The study results showed that there are statistically significant differences between the mean scores of experimental and control groups at the pre- and post-test in the compulsive buying scale, significant at (0.005) in favor of the pre- and post-test. There are also statistically significant differences between the mean scores of the experimental group at the pre- and post-test in the compulsive buying scale, significant at (0.005) in favor of the post-test, i.e. the selective advising program decreased the rate of Compulsive Buying Behavior. The results also showed that there are no statistically significant differences between the mean of the experimental group ranks in the post- and follow-up test, which reveals that the advising program is being effective.
\end{abstract}

Keywords: selective advising program, compulsive buying behavior, Umm Al-Qura

\section{Introduction}

Oniomania is a term that describes compulsive desire or buying obsession. It is called compulsive buying; an obsessive feeling to get artificial and temporary delight that terminates after purchase. It occurs due to emotional vacuum, feeling anxious or fear of refusal. It is utilized as a method of avoiding pressure, feeling good and forgetting sorrows and distress. It indicates impulse control disorder, since it is followed by regret, frustration, anxiety as well as psychological and physical disorders. It is characterized by persistence and negative impact on the individual's performance, family life and financial situation. Although researchers agree on functional weakness associated to the disorder, there is a considerable controversy concerning the classification of Compulsive Buying Disorder (CBD), whether it is a separate disorder or it is associated to another one, such as obsessive compulsive disorder (OCD), mood disorders, or drugs abuse disorders.

Concerning the impact of culture, compulsive buying is seen as a psycho-social phenomenon (Dickie, 2011) or a religious activity (Arya, 2009). CBD often coincides with other disorders, especially anxiety disorders, mood disorders, eating disorders, personality disorders (Black, 2001) and violence in personal relationships.

Such disorder is called compulsive buying because the individual will be busy with shopping and behavior frequency. He also can't control himself when he has the great desire to buy (Filomensky et al., 2011). Furthermore, it causes psychological and social problems in the lives of the people suffering from CBD. Although compulsive buying has received an increased attention in research, it has not received the same attention in clinical practice and has no effective therapy. More studies should be conducted on its diagnosis. Accordingly, advising programs, which treat compulsive buying and its negative impact on the whole community and the individual's delight; family, psychological and professional stability, should be designed.

The American Psychiatric Association (APA), in its DSM-IV, identifies individuals suffering from compulsive buying within indefinite control disorders. Shopaholism is a medical term that refers to the compulsive desire to 
purchase; it is synonym to Oniomania, which is derived from the Greek word onios for sale and mamio for mania.

\subsection{Statement of the Problem}

Several literature indicate that rate of compulsive buying is $5 \%$ in the United States and (5\%-8\%) in Europe, substantially among females. Such disorder often occurs among adolescents (18-30 years). Its ratio among university students is higher than that of other groups; it is $(6 \%-10 \%)$. Perhaps they will have impulsive behaviors, such as compulsive buying and compulsive storage (Brougham et al., 2011). Compulsive buying is one of chronic psychological disorders which occur as a result of personal, social and material complexities. Depression, OCD and hoarding disorder stimulate CBD (Kyrios et al., 2013). Frost et al. (2000) argued that compulsive buying is associated with OCD if it's taken into account that CBD is more comprehensive than abnormal consumption; similar to food and drugs abuse disorders as well as compulsive sexual disorders.

The researcher had meetings with female students, Faculty of Education at Umm Al-Qura University who frequently visits psychological clinics and psychologists to complain about their frequent buying and inability to control such desire. They require the assistance of Psychological Counseling Department to overcome their problem. In addition, some meetings were conducted with some female students who suffer from such disorder to define its reasons. It showed that a high ratio suffer from CBD which results from various causes. More above, there is no Arabic or foreign study that handled the effectiveness of a selective advising program in reducing the degree of CBD. Accordingly, the problem of the present study is defined in the following questions:

1) What is the ratio of compulsive buying prevalence among female students at Umm Al-Qura University?

2) Are there statistically significant differences between the mean scores of experimental and control groups ranks in the CBD pre- and post-application of the advising program?

3) Are there statistically significant differences between the mean scores of experimental and control groups ranks in the CBD after the application of the advising program in favor of the experimental group?

4) Are there statistically significant differences between the mean of the experimental group ranks in compulsive buying in the post- and follow-up scales?

\subsection{Objectives}

The present study aims at identifying the ratio of CBD among female students at Umm Al-Qura University. It also identifies the effectiveness of a selective advising program in reducing the degree of CBD among a sample of female students from Faculty of Education at Umm Al-Qura University and the continuity of the program impact after its application and follow-up within two months.

\subsection{Significance}

Psychologically, the present study tackles CBD, which is a novel and significant variable. It explores such disorder, its criteria, diagnosis, theories which handled it, reasons, methods of treatment, the role of social and cultural aspects and relevant demographic variables. It proposed an advising program to reduce the degree of CBD among a sample of female students from Faculty of Education at Umm Al-Qura University. It designs a psychological tool to measure disorder degree because Psychological and Arabic lacks such psychological measurements. The sample of the study should be provided due care because they are in charge of upbringing future generations. They should also have perfect mental hygiene to be capable of playing their roles, as mothers, properly.

Results shall enable specialists in mental hygiene and psychological counseling to create and implement advising programs which members of the community who suffer from the aforementioned disorder and need treatment and counseling. They provide female school students and parents with preventive and counseling programs to avoid such behaviors.

\subsection{Terms}

Counseling Program: The present study adopts a program based on selection from various schools, theories, techniques and strategies, such as psychological, behavioral, behavioral cognitive and religious analysis.

Compulsive Buying Disorder: Edwards (1993) provides the most prominent definition of compulsive buying. It is an extraordinary form of shopping and expenditure. Consumer suffers from a compulsive, chronic and frequent desire of shopping and expenditure. Compulsive expenditure is a method to reduce negative feelings, such as stress and anxiety. Procedurally, it is the score which the participants obtain after responding to the items of compulsive buying scale. 


\section{Theoretical Framework}

\subsection{Compulsive Buying Disorder (Oniomanaia)}

Psychological researches, particularly those which tackled confusing behaviors, have increasingly handled CBD (Black, 2001). Emil Kraepelin was the first to tackle and specify Oniomania in his report in 1915. It is defined as total preoccupation with buying or its motivations which can't be resisted. Buying behavior results in remarkable depression and contradicts with social behavior and leads to economic problems (Osso et al., 2008; Pazarlis et al., 2008). McElory et al. (1991) stated that compulsive buying is related to other psychological disorders, such as mood, anxiety and impulse control disorder. They suggested incorporating it into Diagnostic and Statistical Manual of Mental Disorders-DSM-IV-TR as impulse control disorder (Lee \& Mysyk, 2004). Koran et al. (2006) examined compulsive buying and proposed diagnostic definitions and criteria, including stress and low performance associated with such disorder. Moore (2009) also presented diagnostic criteria, so the disorder has numerous definition and diagnostic criteria (Hollander \& Allen, 2006).

Edwards (1993) argued that there are five levels of consumer behavior: non-compulsive purchase, recreational purchase, low compulsive purchase, compulsive purchase, and addictive purchase. Non-compulsive buyers tend to plan for what they buy, but those who buy for recreation tend to improve their mood, so they often buy in a hurry and without planning. Low compulsive buyers have similar tendencies as they can highly improve their mood, but they feel guilty after buying what they don't actually need. Compulsive purchasers buy to reduce stress and anxiety. They also feel depressed when they get items they don't need. Whereas, buying addicts have a constant and strong desire to buy things. Thus, they may neglect many social relations as well as demographic and cultural variables. Compulsive buying is associated with demographic elements, such as the consumer's age and gender. Results of the studies that handle the relation between age and compulsive buying reveal that youth are terribly affected comparing to other age groups.

\subsubsection{Characteristics of Compulsive Buyers}

- $\quad$ They prefer to go shopping alone because they are afraid to be condemned by others.

- Collectors spend much time searching for valuables to keep and brag about. The compulsive buyers focus on the purchasing process itself, so they do not care about what they buy. So, they may try to hide, store, or get rid of what they bought.

- $\quad$ They make great efforts and frequent attempts to stop CBD, but they fail.

- After buying, they feel ashamed and guilty.

- They show impulsive behaviors, do things at the moment of motivation, feel frustrated when they cannot get what they want. They find it difficult to establish and maintain affection and affability with others, so they feel lonely and isolated. These behaviors are observed among addicts and individuals with eating disorders.

- Most buyers go shopping to reduce depression and to raise their spirit (Ertelt et al., 2009; Workman, 2010; Lejoyeux \& Weinstein, 2010; Dickie, 2011; Shanmugam, 2011).

Compulsive buying is associated with lack of self-regulation and self-control, low self-esteem, depression, anxiety, food disorders (Bulimia), kleptomania, and lack of emotional awareness and perseverance.

\subsubsection{Theories of Compulsive Buying and its Causes}

Disease theory and biological factors

Impulsive disorders, such as compulsive buying, can be understood as dysfunctional neurocircuits and rewards behaviors. Neurotransmitter dysfunction, i.e. dopamine and Serotonin (hormones of mood regulation) results in compulsive buying and reward behaviors. In other words buying becomes a delightful and interesting process which changes the brain chemistry. Compulsive buying has a normal genetic basis (Ertelt et al., 2010; Lejoyeux \& Weinstein, 2010; Workman, 2010; Dickie, 2011).

Psychodynamic and Psychological Factors

Compulsive buying occurs as a response to and a method to escape and reduce negative impulses. Impulsivity contributes to compulsive buying where rapid and unplanned responses occur (for both internal and external stimulant) and minimizing the negative results (Lejoyeux \& Weinstein, 2010). It involves unpleasant ideas and stressful family events, such as divorce. Accordingly, it is a mechanism addicted to deal with psychological tension through escape or avoidance. Addictive purchasing begins as a pleasant and interesting behavior that turns to preoccupation and addiction. It can be also a co-existence response rooted in the individual's early 
experiences "child-parents relationship". On the other hand, buying behavior provides self-rebalance and self-nurturing, regulates disconnected sense, and improves self-identity (Wang, 2007; Ertelt et al., 2010; Weaver et al., 2011)

\section{Dickie Model of CBD}

It comprises four phases: Anticipation, Preparation, Shopping, and Spending. First, the individual feels occupied with purchasing and developing his motives towards purchases. Next, s/he prepares for shopping through the following steps: What will s/he wear? Where will s/he go? Which credit cards will s/he use? Then he buys and spends. Eventually, he feels guilty and regretful (Dickie, 2011).

\subsubsection{Consequences of CBD}

\section{Positive Short-term Results}

Compulsive buyers experience some positive results and reinforcement through their behavior, including reducing stress and tension, feeling delighted and entertained, reforming self-concept, reinforcing self-esteem and self-respect and getting over feelings of psychological loneliness and negative emotions. Such positive feelings motivate purchasers to repeat CBD as a means of self-support.

\section{Negative Long-term Results}

Despite the positive results of CBD, the long-term results are harmful and negatively impact the individual. They are represented in personal grief and financial debts, marital and family turmoil, legal problems, confusion of interpersonal relationships, low self-esteem, self-criticism, criticism of others, feelings of guilt, anxiety, lying, addiction, isolation, and suicide attempts (Ertelt et al., 2009; Workman, 2010, Weaver et al., 2011; Muller et al., 2011; Dickie, 2011).

\subsubsection{Treatment for CBD}

It is difficult to treat CBD because purchasing cannot be canceled from the individual's life. Limited research about CBD was conducted and there is no specific treatment for it. Using drugs and psychotherapy paves the way for treatment. Antidepressants reduce the desires for compulsive behavior, while Serotonin organizes purchasing motives. Moreover, psychological analysis and cognitive behavioral therapy effectively treat compulsive buying. Psychological analysis helps to understand and know the causes of the individual's negative emotions, depression and anxiety, and low self-esteem (Pazarlis et al., 2008; Ertelt et al., 2009; Muller et al., 2011; Dickie, 2011).

\subsection{Review of the Literature}

Young et al. (2006) analyzed a 24 year-old Korean female with CBD and excessive credit card use over nine months. Her behavior resulted in various debts and negatively influenced her family and interpersonal relations. The study aimed to identify the effectiveness of family therapy in reducing compulsive buying and the factors affecting CBD. The total number of sessions was 15, taking place from 2001 to 2004 . The types of therapy were comprised of individual sessions, parents sessions, family sessions, and phone-call sessions. Results revealed that $\mathrm{CBD}$ comes as a response to anxiety, depression, stress, and family problems.

Mitchell et al. (2006) aimed to identify the effectiveness of cognitive behavioral therapy in treating CBD. The sample consisted of 28 participants (experimental group) and 11 participants (control group). Yale-brown obsessive compulsive scale and shopping version and the compulsive buying scale were used. Results demonstrated the effectiveness of cognitive behavioral therapy in reducing obsessional thoughts associated with CBD and shopping time. Also, positive results lasted after six months.

Darabshi (2015) aimed to identify the relation between CBD and other psychological disorders. The sample consisted of (88) female students from King Saud University. The author used compulsive buying scale and the Symptom Checklist-90 (by Almohareb and Al Naem) which proved its validity and reliability. The study results showed that there are statistically significant relation between CBD and other psychological disorders, including general anxiety, depression, OCD, Somatization disorder, psychosis, Paranoia, aggressiveness and phobia.

\section{Methodology}

The quasi-experimental approach was utilized through two groups (experimental and control). Pre-, post- and follow-up assessment was applied to the participants. Such approach is consistent with the objective of the present study which attempts to investigate the effectiveness of a selective advising program in reducing the degree of CBD. 


\subsection{Sampling Procedures}

The compulsive buying scale was applied to (200) female students from Faculty of Education $\left(2^{\text {nd }}, 3^{\text {rd }}\right.$ and $4^{\text {th }}$ level students at Kindergarten and Special Education Departments) at Umm Al-Qura University. (10) Female students got the highest scores and participated in the advising program as a sample of both groups (experimental and control).

According to the following table, Mann-Whitney Equation was used to estimate the compatibility of both the experimental and control groups at compulsive buying variable:

Table 1. Results of estimating $(Z)$ value for the mean scores of the experimental and control groups ranks at the pre-test in the compulsive buying scale

\begin{tabular}{|c|c|c|c|c|c|c|c|}
\hline \multirow{3}{*}{ Research Variables } & \multirow{2}{*}{\multicolumn{2}{|c|}{$\begin{array}{l}\text { Experimental Group } \\
\qquad \mathrm{N}=10\end{array}$}} & \multirow{2}{*}{\multicolumn{2}{|c|}{$\begin{array}{c}\text { Control Group } \\
\mathrm{N}=10\end{array}$}} & \multirow{3}{*}{ Mann-Whitney- U Coefficient } & \multirow{3}{*}{$\mathrm{Z}$} & \multirow{3}{*}{ Significance } \\
\hline & & & & & & & \\
\hline & Ranks Mean & Ranks Total & Ranks Mean & Ranks Total & & & \\
\hline Age Level & 112 & 112 & 9.8 & 98 & 43 & 532 & insignificant \\
\hline
\end{tabular}

Table 1 reveals that there are no statistically significant differences, i.e. there is equivalence between means of the experimental and control groups ranks at the pre-test in the compulsive buying scale. (Z) Value is statistically insignificant, so both groups are highly equivalent.

\subsection{Tools}

\subsubsection{Compulsive buying Scale}

The author reviewed theoretical framework and previous literature which tackled compulsive buying scale, such as excessive buying scale (Galal, 2012) and Moore (2009) scale. However, these scales are inappropriate for estimating such variable in Saudi Arabia. Consequently, another scale appropriate for the population of the present study (Saudi Arabian female students) was prepared. It comprises 32 paragraphs that measure the degree of compulsive buying among female students at Umm Al-Qura University.

Standardization Sample: the scale was applied to (80) female students at Umm Al-Qura University.

\subsubsection{Psychometric Characteristics of the scale}

Reviewers Validity: 10 Faculty members of Mental Hygiene at some Saudi Arabia Universities were electronically asked to examine the dimensions of the scale, according to its appropriateness for the variable, Paragraph's consistency with dimension, Paragraph's appropriate wording, and adjusting, adding and deleting some paragraphs. Reviewers' agreement to 24 paragraphs was $90 \%$ after omitting (5) paragraphs due to their frequency or inappropriateness. Thus, total numbers of the paragraphs was 27. Responses involve five phrases (always, very often, sometimes, rarely, never) (5-4-3-2-1), i.e. Scale is checked according to Fifth Likert Scale (5-4-3-2-1). Accordingly, total score is (27-135). The highest score indicates excessive compulsive buying, while the lowest reveals mild compulsive buying (or none).

Internal Validity: Correlation Coefficient between the score of each paragraph and total score in the scale was estimated after subtracting the paragraph's score from the total score and the other paragraphs have to be taken into account. Table (2) indicates the paragraphs validity in compulsive buying scale.

Table 2. Internal validity of the scale paragraphs $(\mathrm{N}=80)$

\begin{tabular}{cccccc}
\hline Paragraph No. & Its Relation to Total Score & Paragraph No. & Its Relation to Total Score & Paragraph No. & Its Relation to Total Score \\
\hline 1 & $0.389^{* *}$ & 10 & $0.519^{* *}$ & 19 & $0.548^{* *}$ \\
2 & $0.485^{* *}$ & 11 & $0.518^{* *}$ & 20 & $0.349^{* *}$ \\
3 & $0.441^{* *}$ & 12 & $0.446^{* *}$ & 21 & $0.425^{* *}$ \\
4 & $0.483^{* *}$ & 13 & $0.483^{* *}$ & 22 & $0.502^{* *}$ \\
5 & $0.638^{* *}$ & 14 & $0.518^{* *}$ & 23 & $0.446^{* *}$ \\
6 & $0.450^{* *}$ & 15 & $0421^{* *}$ & 24 & $0.518^{* *}$ \\
7 & 0.481 & 16 & $0.566^{* *}$ & 25 & $0.415^{* *}$ \\
8 & $0.5150^{* *}$ & 17 & $0.347^{* *}$ & 26 & $0.514^{* *}$ \\
9 & $0.418^{* *}$ & 18 & $0379^{* *}$ & 27 & $0.451^{* *}$ \\
\hline
\end{tabular}

** Means that the paragraph is statistically significant at 0.01 . 
Table 2 illustrates that all paragraphs have statistically significant correlation with total score in the scale, i.e. the scale involves a high degree of internal validity which indicates that paragraphs participate in measuring compulsive buying degree.

\subsubsection{Reliability of Compulsive Buying Scale}

The scale reliability was calculated using three methods: a. Spearman-Brown Split-half, b. Cronbach's Alpha coefficient, c. Re-application (the scale was re-applied to 35 students from the sample after the passage of three weeks on the first application and calculated the correlation coefficient between the two applications). Table 3 shows the reliability coefficients of the three methods of the scale as a whole.

Table 3. Reliability coefficients of compulsive buying scale $(\mathrm{N}=80)$

\begin{tabular}{lll}
\hline Split-half & Cronbach's Alpha & Reapplication \\
\hline 0.817 & 0.857 & 0.867 \\
\hline
\end{tabular}

Table 3 indicates the scale is reliable, so it will be conveniently utilized.

\subsubsection{Final Form of the Scale}

Final form of the scale comprises 27 valid and reliable paragraphs applicable to the study sample.

\subsection{The Advising Program}

Attempting to benefit from theories and schools of psychology, the author prepared advising program based on Selection Theory. The program aims to reduce the degree of CBD among a sample of female students from Faculty of Education at Umm Al-Qura University.

\subsubsection{Contents of the Advising Program}

Benefit from the advising program and various behavioral programs to reduce the degree of psychological and behavioral disorders. The author also used group counseling in some sessions to motivate the participants to interact and share their experiences. Whereas, the individual counseling was used in other sessions.

\subsubsection{Advising Sessions}

The author prepared (10) group sessions (over 5 weeks, 2 sessions per week) for the participants of the selective advising program. Each session was 50-60 minutes and a follow-up session was conducted a month later. Sessions had been conducted in Psychology Laboratory at Faculty of Education. Table (4) indicates a summary of the sessions. 
Table 4. A summary of the selective advising program

\begin{tabular}{|c|c|}
\hline $\begin{array}{l}\text { Type of the } \\
\text { Program }\end{array}$ & Selective Advising \\
\hline General Objective & Reducing the degree of compulsive buying among a sample of university female students. \\
\hline \multirow{3}{*}{ Special Objective } & $\begin{array}{l}\text { At the end of the program, the participants will be capable of identifying CBD, various strategies and skills that help } \\
\text { reduce the degree of } \mathrm{CBD} \text {, as well as motives, symptoms, triggers, and emotional symptoms of CBD which force the } \\
\text { individual to spend much time shopping aimlessly and buying unrequired things. }\end{array}$ \\
\hline & $\begin{array}{l}\text { They can also identify the emotions relevant to CBD, either when they have psychological suffering and marital and } \\
\text { family disturbed relations or when they feel worried. }\end{array}$ \\
\hline & $\begin{array}{l}\text { They also gain positive experiences which enable them to overcome such disorder in their social and scientific life, } \\
\text { increase their self-confidence and self-control in distress. }\end{array}$ \\
\hline Sampling & 10 female students who tend to provide help and frequently visit Department of Psychology at Faculty of Education \\
\hline Program Designer & The author \\
\hline $\begin{array}{l}\text { Place of } \\
\text { implementation }\end{array}$ & Psychology laboratory at the faculty. \\
\hline No. of Sessions & (10) Group selective advising sessions, including individual sessions and a follow-up session after a month. \\
\hline Session Duration & $50-60$ minutes \\
\hline Program Duration & Five weeks. \\
\hline Tools & Laptop- PowerPoint- Projector-movies-pens-material \\
\hline $\begin{array}{l}\text { Methods of } \\
\text { Evaluation }\end{array}$ & Pre-, post- and follow-up compulsive buying scale \\
\hline
\end{tabular}

Table 5. A summary of the advising sessions

\begin{tabular}{|c|c|c|c|}
\hline $\begin{array}{l}\text { No. of } \\
\text { Session }\end{array}$ & Title & Objectives & Methods and Techniques \\
\hline $1^{\mathrm{st}}+2^{\text {nd }}$ & $\begin{array}{c}\text { Introducing and } \\
\text { identifying the } \\
\text { program }\end{array}$ & $\begin{array}{l}\text { Reciprocal understanding between the researcher and the participants, } \\
\text { building a successful advising relation and affability. } \\
\text { Explaining the program and the desired benefit. } \\
\text { Setting regulations for sessions. } \\
\text { Confirming confidentiality and privacy within sessions. } \\
\text { Explaining the researcher and the participants' role in the program. } \\
\text { Illustrating the objectives and significance of the program. }\end{array}$ & $\begin{array}{l}\text { Discussion } \\
\text { Group dialogue }\end{array}$ \\
\hline $3^{\text {rd }}$ & Material on CBD & $\begin{array}{l}\text { Identifying CBD } \\
\text { Identifying its symptoms, motives and consequences. } \\
\text { Identifying its triggers. } \\
\text { Discussing methods of minimizing and mitigating CBD. } \\
\text { Identifying psychological stress, its sources, causes and effects. }\end{array}$ & $\begin{array}{l}\text { Lecture and discussion } \\
\text { Assignment } \\
\text { Insight Catharsis } \\
\text { Brainstorming }\end{array}$ \\
\hline $4^{\text {th }}$ & $\begin{array}{l}\text { Educational } \\
\text { material on } \\
\text { psychological } \\
\text { stress and } \\
\text { mechanisms of } \\
\text { overcoming it. }\end{array}$ & $\begin{array}{l}\text { Training on using positive ways to confront psychological stress and avoid } \\
\text { psychological disorders. } \\
\text { Presenting real examples on the individuals who suffered from CBD, and } \\
\text { methods of mitigating such disorders. } \\
\text { Facing the problem } \\
\text { Making new friendships and creating ideas that help change the participants' } \\
\text { attitude towards CBD. }\end{array}$ & $\begin{array}{l}\text { Discussion about } \\
\text { emotional ventilation } \\
\text { role play } \\
\text { Cognitive reconstruction } \\
\text { of ideas } \\
\text { Assignment }\end{array}$ \\
\hline $5^{\text {th }}$ & $\begin{array}{l}\text { Time planning and } \\
\text { management }\end{array}$ & $\begin{array}{l}\text { An educational lecture to identify time and its importance, including some } \\
\text { prophetic sayings that tackle the importance of time and how the individual } \\
\text { spent it. } \\
\text { Some instructions on time management and setting schedule for every task. }\end{array}$ & $\begin{array}{l}\text { Lecture and discussion, } \\
\text { Feedback, } \\
\text { Assignment, and } \\
\text { Cognitive } \\
\text { Reconstruction }\end{array}$ \\
\hline
\end{tabular}




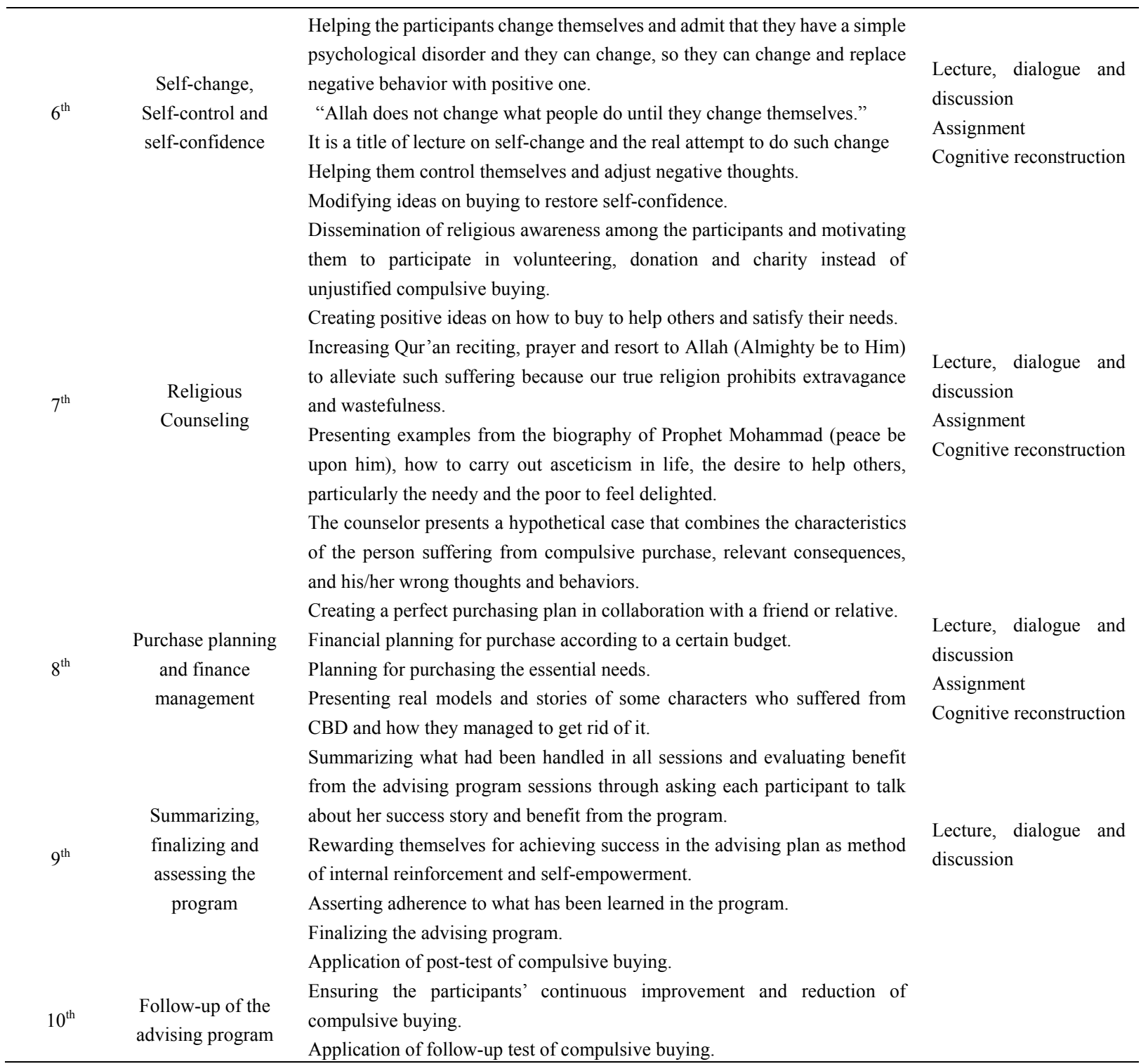

\subsubsection{Evaluating the Program}

Ten Reviewers in the field of mental hygiene, psychological counseling and psychology had examined the preliminary form of the program to make sure that the applied and methodological procedures of the program follow the instructions. Simple modification was conducted to present the program in its final form.

The compulsive buying scale was applied to 200 female students (20-30 year) from the Faculty of Education. Female students who got the highest scores were selected to participate in the program application.

The program was applied to the sample. Compulsive buying scale was applied after the end of the programs sessions. It was also applied after follow-up period to make sure of the programs continuous effectiveness.

Some non-parametric statistical methods, including arithmetic mean, standard deviation, Wilcoxon test, and Mann-Whitney test were utilized to make sure of the hypotheses validity.

\section{Results and Discussion}

The first Question (Psychometric): What is the ratio of compulsive buying prevalence among female students at Umm Al-Qura University?

The question can be answered in the light of the three levels of compulsive buying (high-moderate-low), as follows: Always occur, moderately occur, and rarely occur.

Frequencies and percentages of the three levels of the descriptive sample (200 female students from the 
educational and scientific departments), were estimated according to the following table:

Table 6. Frequencies and percentages of the participants (200 female students) in the compulsive buying scale

\begin{tabular}{|c|c|c|c|c|c|c|c|c|}
\hline \multirow[b]{2}{*}{ Variable } & \multicolumn{2}{|c|}{ High (More) } & \multicolumn{2}{|c|}{$\begin{array}{l}\text { Moderate } \\
\text { (Mild) }\end{array}$} & \multicolumn{2}{|c|}{ Low } & \multirow[b]{2}{*}{ Frequencies } & \multirow[b]{2}{*}{$\begin{array}{c}\text { Total } \\
\text { Percentage } \%\end{array}$} \\
\hline & 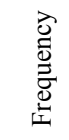 & $a^{\circ}$ & 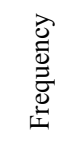 & $a^{0}$ & 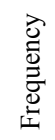 & $0^{\circ}$ & & \\
\hline 1-I tend to go shopping frequently. & 150 & 75 & 35 & 17.5 & 15 & 7.5 & 200 & 100 \\
\hline $\begin{array}{l}\text { 2-Shopping decreases my psychological } \\
\text { suffering and social stress. }\end{array}$ & 50 & 25 & 120 & 60 & 30 & 15 & 200 & 100 \\
\hline 3-I go shopping to improve my mood. & 100 & 50 & 60 & 30 & 40 & 20 & 200 & 100 \\
\hline $\begin{array}{l}\text { 4-I go shopping to feel relieved when I } \\
\text { have a problem. }\end{array}$ & 90 & 45 & 75 & 37.5 & 35 & 17.5 & 200 & 100 \\
\hline $\begin{array}{l}\text { 5-Shopping reduces my anxiety and } \\
\text { tension. }\end{array}$ & 100 & 50 & 70 & 35 & 30 & 15 & 200 & 100 \\
\hline $\begin{array}{l}\text { 6-I feel entertained when I go shopping, } \\
\text { whether I need the item or not. }\end{array}$ & 45 & 22.5 & 65 & 32.5 & 90 & 45 & 200 & 100 \\
\hline $\begin{array}{l}\text { 7-I spend much time shopping when } \\
\text { people don't accept me. }\end{array}$ & 150 & 75 & 40 & 20 & 10 & 5 & 200 & 100 \\
\hline $\begin{array}{l}\text { 8-My interest in shopping negatively } \\
\text { affects my social relations. }\end{array}$ & 170 & 85 & 29 & 14.5 & 1 & 0.5 & 200 & 100 \\
\hline $\begin{array}{l}\text { 9- I go shopping alone because I don't } \\
\text { like to be criticized. }\end{array}$ & 130 & 65 & 55 & 27.5 & 15 & 7.5 & 200 & 100 \\
\hline $\begin{array}{l}\text { 10-I aimlessly buy, so I spend much } \\
\text { money. }\end{array}$ & 160 & 80 & 34 & 17 & 6 & 3 & 200 & 100 \\
\hline 11-I spend much time shopping. & 95 & 47.5 & 70 & 35 & 35 & 17.5 & 200 & 100 \\
\hline $\begin{array}{l}\text { 12-I feel regretful because I buy various } \\
\text { things I don't need. }\end{array}$ & 85 & 42.5 & 95 & 47.5 & 20 & 10 & 200 & 100 \\
\hline $\begin{array}{l}\text { 13-My desire to purchase increases after } \\
\text { watching commercials and method of } \\
\text { presentation. }\end{array}$ & 75 & 37.5 & 100 & 50 & 25 & 12.5 & 200 & 100 \\
\hline $\begin{array}{l}\text { 14-If I don't go shopping, I feel anxious } \\
\text { and tense. }\end{array}$ & 105 & 52.5 & 85 & 42.5 & 10 & 5 & 200 & 100 \\
\hline $\begin{array}{l}\text { 15-My desire to purchase increases after } \\
\text { feeling nervous and stressed. }\end{array}$ & 65 & 32.5 & 110 & 55 & 25 & 27.5 & 200 & 100 \\
\hline $\begin{array}{l}\text { 16-I feel psychologically relieved after } \\
\text { purchase. }\end{array}$ & 70 & 35 & 100 & 50 & 30 & 15 & 200 & 100 \\
\hline 17-I feel myself when I go shopping. & 100 & 50 & 80 & 40 & 20 & 10 & 200 & 100 \\
\hline $\begin{array}{l}\text { 18-People, who know me, get annoyed } \\
\text { because I frequently go shopping. }\end{array}$ & 120 & 60 & 70 & 35 & 10 & 5 & 200 & 100 \\
\hline $\begin{array}{l}\text { 19-I postpone important family affairs } \\
\text { due to shopping. }\end{array}$ & 175 & 87.5 & 15 & 7.5 & 10 & 5 & 200 & 100 \\
\hline $\begin{array}{l}\text { 20-After shopping, I feel delighted, } \\
\text { frustrated and guilty. }\end{array}$ & 155 & 77.5 & 10 & 5 & 35 & 17.5 & 200 & 100 \\
\hline $\begin{array}{l}\text { 21-I hide annoyance and frustration } \\
\text { feelings while shopping. }\end{array}$ & 135 & 67.5 & 20 & 10 & 45 & 22.5 & 200 & 100 \\
\hline $\begin{array}{l}\text { 22-I attempt to satisfy my family } \\
\text { members with the necessity of my } \\
\text { purchases. }\end{array}$ & 95 & 47.5 & 45 & 22.5 & 60 & 30 & 200 & 100 \\
\hline $\begin{array}{l}\text { 23-I go shopping when the individuals, I } \\
\text { know, disregard me. }\end{array}$ & 165 & 82.5 & 25 & 12.5 & 10 & 5 & 200 & 100 \\
\hline 24-I eagerly and excitedly go shopping. & 80 & 40 & 65 & 32.5 & 55 & 27.5 & 20 & 100 \\
\hline
\end{tabular}




\begin{tabular}{|c|c|c|c|c|c|c|c|c|}
\hline $\begin{array}{l}\text { 25-Shopping provides me with } \\
\text { temporary delight, followed by } \\
\text { annoyance. }\end{array}$ & 150 & 75 & 15 & 7.5 & 25 & 12.5 & 200 & 100 \\
\hline $\begin{array}{l}\text { 26-I frequently go shopping as long as I } \\
\text { am not in the mood. }\end{array}$ & 150 & 75 & 25 & 12.5 & 15 & 7.5 & 200 & 100 \\
\hline $\begin{array}{l}\text { 27-I excessively and inconveniently go } \\
\text { shopping. }\end{array}$ & 110 & 55 & 80 & 40 & 10 & 5 & 200 & 100 \\
\hline
\end{tabular}

Results of Table 6 are as follows:

High rate of compulsive buying is prevalent among the participants (21 out of 27 paragraphs). All paragraphs represent high rate except paragraphs No. 2, 6, 12, 13, 15, and 16. (21) Paragraphs indicate urgent desire of CBD among females. Such desire results from various factors, such as being a frequent habit, reducing feelings of pain and annoyance, sorrow and family or social stress, and her tendency to buy, whether she needs the item or not. She also feels delighted during shopping. She persistently tries to convince her family with her purchases. She sees that purchase enables her to overcome anxiety and disappointment. Accordingly, she endeavors to find reasons and justifications, either psychological or temperamental, to satisfy her desire and achieve her compulsive desire of buying.

Moderate rate of buying is obviously low; it was observed in (5) paragraphs only $(2,12,13,15,16)$, while its percentage was relatively high. Shopping decreases psychological suffering and social stress. She feels regretful because she buys various things she doesn't need. Her desire to purchase increases after watching commercials and method of presentation. She is relieved after purchase.

Low rate of compulsive buying is so rare; it was obvious in one paragraph (6), I feel entertained when I go shopping, whether I need the item or not.

Result of the study assures the prevalence of CBD among female university students, in particular, and women, in general, despite the diversity of its triggers.

CBD is a common behaviour among adolescent as well as university students (18-30). The present study also indicated that teenagers have tendencies to buy compared to other age groups. Moreover, the present study demonstrated that adolescent females are more prone to CBD due to the culture of Saudi community and the high standard of living among some families. Consequently, many individuals prefer welfare, purposeful and non-purposeful shopping, buying necessary and unnecessary items and the unconscious openness of shopping world.

Nevertheless, we cannot generalize such result in the light of the Saudi community's religious values and behavioral ethics which assert spending moderately and prevent extravagance. The program showed that participants liked buying to improve their mood and to relieve psychological stress and anxiety, whatever the cost and the negative results. However, they temporarily feel happy because they face a strong and urgent desire for buying which negatively impacts their social responsibilities.

Results of the second Question: Are there statistically significant differences between the mean scores of experimental and control groups ranks in CBD before and after the application of the advising program to the experimental group?

Mann-Whitney Equation is used to answer the second question as follows:

Table 7. Results of estimating "Z" value of the means of the experimental and control group ranks at the pre- and post-test

\begin{tabular}{lcccccc}
\hline Variable & Ranks & Number & Ranks Mean & Total Ranks & Z & Significance \\
\hline \multirow{5}{*}{ Compulsive Buying } & $\begin{array}{c}\text { Negative Ranks } \\
\text { Positive Ranks } \\
\text { Equal Ranks } \\
\text { Total }\end{array}$ & 0 & Zero & Zero & & \\
& 10 & & & 2.805 & 0.005 \\
\hline
\end{tabular}

Table 7 indicates statistically significant differences between the mean scores of experimental and control groups at the pre- and post-test in the compulsive buying scale, significant at (0.005) in favor of the post-test. 
Results of the third Question: Are there statistically significant differences between the mean scores of experimental and control groups ranks in CBD before and after the application of the advising program?

Wilcoxon equation is used to answer the third question as follows:

Table 8. Results of estimating " $Z$ " value of the mean scores of the experimental group ranks at the pre- and post-test in the compulsive buying scale

\begin{tabular}{lcccccc}
\hline Variable & Ranks & Number & Ranks Mean & Total Ranks & Z & Significance \\
\hline \multirow{5}{*}{ Compulsive Buying } & $\begin{array}{c}\text { Negative Ranks } \\
\text { Positive Ranks } \\
\text { Equal Ranks } \\
\text { Total }\end{array}$ & 0 & Zero & Zero & & \\
& 0 & & & 2.805 & 0.005 \\
\hline
\end{tabular}

Table 8 indicates statistically significant differences between the mean scores of experimental groups ranks at the pre- and post-test in the compulsive buying scale, significant at (0.005) in favor of the post-test, i.e. The advising program reduced the degree of compulsive buying scale.

\section{Discussion}

Zahran (1989) stated that group psychotherapy effectively reduces anxiety and tension and increases self-confidence. Advising groups assert such perspective because interaction and affability among participants reinforced sincerity and self-confidence and enabled them to learn and teach new behaviors. Variety of techniques used in the selective religious advising program motivated the participants to reduce the degree of CBD and face psychological problems during the program application. Religious counseling provides the individual with pleasure, satisfaction and belief in fate and destiny. That's why; the individual will have the ability to face stress and problems. He will also have self-confidence and power which helm him/her to overcome challenges and crises in life. Accordingly, he/she will feel secured and optimistic. Also, he will be confident that no one except Allah (Almighty be to Him) will change his state to better through prayer, Allah's remembrance, reciting the Holy Qu'ran, reliance on Allah, and endeavoring reassurance. So, the individual, bestowed with such virtues, will enjoy psychological adjustment.

Religious counseling program provided the participants with some values and principles and motivated them to do some voluntary charitable deeds and to help the orphans and the poor. It had a great impact on the hearts of participants and reduced internal psychological conflicts, tension, and annoyance during the process of unjustified spending and compulsive buying.

Religious counseling and psychotherapy are relevant to the culture, beliefs, and Islamic values of the advising group participants. They helped participants to change and learn new behaviors. Some techniques motivated the participants to express their inner feelings and conflicts, to let off some steam in the discussions and group dialogues, and to detect all the troubles and problems that made them spend most of their time in the compulsive purchasing process to get rid of their excitement. Their motives were also understood, so they were more self-confident and capable of overcoming such problem and controlling their behaviors.

Therefore, the effectiveness of the religious selective counseling program in reducing the seriousness of CBD among the participants in the program has been indicated. The participants, who attended the sessions, stated that CBD deprived them of their most enjoyable moments and incurred many health and material losses. They also get the item for no reason. They go shopping when they lack family pleasure or face a problem. They foster the concept that compulsive buying relieves their psychological suffering and bestows them self-confidence. Whereas, some participants pointed out that compulsive buying is similar to addiction in terms of irresistible motivation; they lose control and balance and continue to buy despite the consequences and financial losses. A participant indicted that she goes shopping alone because she hates criticism. She also stated that purchase provides her happiness, which may be temporary, although it involves several negative consequences. CBD helped the participants kill their leisure and get rid of their negative emotions despites of its psychological effect and negative consequences.

Moreover, the insight technique motivated the participants to quietly express themselves, to change their behaviors and emotions, to observe their conducts, and to express improper concepts to be replaced with proper, real and positive ones. They also learnt some rational and positive concepts. Accordingly, they felt relieved.

Cognitive building technique made them modify their improper concept and replace them with proper one and 
control themselves and positively manage their time to organize their life and benefit from it. It also taught them planning and creating budget properly. As a result, they could resist such concepts and motives which attract them towards compulsive buying. They also felt self-confidence.

Result of the present study indicated the effectiveness of the advising program. Compulsive shoppers go shopping to feel happy. However, such happiness is temporary because guilt and frustration will follow it. It is a continuous act because compulsive buyers attempt to reinforce their identity, get social acceptance, attract attention, and increase self-esteem through getting the others presents.

Result of the present study is consistent with some studies, such as Young et al. (2006); Muller et al. (2011); Darabshi (2015), and Al-Nabati (2011) which proved the effectiveness of the program, methods and strategies in reducing CBD.

Results of the fourth Question: Are there statistically significant differences between the mean scores of experimental group at the post and follow-up test in the compulsive buying scale?

Table 9. Results of estimating "Z" value of the mean scores of the experimental group ranks at the post- and follow-up test in the compulsive buying scale

\begin{tabular}{lcccccr}
\hline Variable & Ranks & Number & Ranks Mean & Total Ranks & Z & Significance \\
\hline \multirow{5}{*}{ Compulsive Buying } & Negative Ranks & 6 & 6.17 & 37 & & \\
& $\begin{array}{c}\text { Positive Ranks } \\
\text { Equal Ranks }\end{array}$ & 4 & & & 3.29 & insignificant \\
& Total & 10 & 4.5 & 18 & & \\
\hline
\end{tabular}

Table 9 reveals that there are no statistically significant differences between the means of the experimental group ranks in the post- and follow-up test, which reveals that the advising program is effective.

The effectiveness of the religious and selective advising program in reducing the degree of CBD among a sample of female students from Faculty of Education at Umm Al-Qura University over a two-month follow up is illustrated in behavioral changes because the program aimed to motivate the participants to apply what they have learned in order not to behave negatively as before. They also have to control false thoughts, stress and psychological problems which cause compulsive buying.

The author sees that the participants have to consult a family member or friends before buying any item. They also should adhere to good planning for time management and financial planning for purchases management. In addition, they should help the poor and the needy and solve their problems through devoting them specific time. As a result, they diminished purchasing motives where were previously irresistible. They started to feel glad, so their feelings of tension, guilt and anxiety reduced. They also were motivated to apply what they learned in the program.

\section{Recommendations}

The present study recommends the following: 1) Specialists in mental hygiene and psychological counseling should provide symposia and lectures on the concept of CBD, its negative consequences; psychological, social and health problems for the individual and community and methods of reduction at school and universities; 2) Providing courses on time and financial managment because Allah will ask the believer about spending his time and how he earned and spent his income; 3) Motivating the adolescents to participate in voluntary and charitable work to share the others' suffering, to learn from real experiences and to teach them selflessness; 4) Parents should provide their kids love, care and attention to be psychologically sound and self-confident because such characteristics will protect them from negative consequences and psychological disorders, such as compulsive buying; 5) Raising the family awareness about the necessity of admitting any disorder that affects them, especially if it caused distress or many problems which have no logical explanation. Such method is the substantial therapy for these emotional and behavioral disorders; 6) the necessity of utilizing compulsive buying scale in addition to the other tools of diagnosis when examining CBD.

\section{References}

Al-Nabati, A. F. (2011). Compulsive collection and storage and their relation to compulsive obsession the light of some demographic variables among a clinical and non-clinical sample (Unpublished master thesis). Faculty of Education. Umm Al-Qura University. 
Arya, R. (2009). The Religious Dimensions of Compulsive Buying. Equinox Publishing Ltd, 12(20), 165-185.

Black, D. W. (2001). Compulsive buying behavior: Definition, assessment, epidemiology and clinical management. Therapy in Practices, 15(1), 17-27.

Brougham, R., Jacobs-Lawson, J., Hershey, D., \& Trujillo, K. (2011). Who pay your debt? An important question for understanding compulsive buying among American college student. International Journal of Consumer Studies, 79-95. https://doi.org/10.1111/j.1470-6431.2010.00923.x

Darabshi, J. M. (2015). Compulsive buying behavior and its relation to some other psychological disorders. Arabic Studies in Education and Psychology, 57, 341-371.

Dickie, J. (2011). A phenomenological study of the experience and meaning of compulsive buying and mood and/ or anxiety disorders. $\mathrm{PhD}$ thesis. North central University. Umi N: 348921d.

Echert, B. A. (2009). Femal e victims of interpersonal violence and its association with compulsive buying. Doctor of Psycgology. Campbella University.Umi N.3380460.

Edwards, E. A. (1993) Development of a new scale for measuring compulsive buying behavior. Financial counseling and planning, 4, 67-84.

Ertelt, T. W., Marino, J. M., Mitchell, J. E., \& Lancaster, K. (2009). Current status of cognitive-behavioral intervention for compulsive Buying disorder. Contempt Psychotherapy, 39, 213-220. https://doi.org/10.1007/s10879-009-9121-9

Ertelt, T., Marino, J., \& Muller, A. (2010). Etiology of compulsive puling, In A. Muller, \& J. Mitchell (Eds.), Compulsive Buying: Clinical Foundation and Treatment. Taylor \& Francis

Filomensky, T. Z., Almeida, K. M., Nogueira, M. C. C., Diniz, J. B., Lafer, B., Borcato, S., \& Tavares, H. (2011). Neither bipolar nor obsessive-compulsive disorder: Compulsive buyers and impulsive acquires. Comprehensive Psychiatry, 53(5), 554-561. https://doi.org/10.1016/j.comppsych.2011.09.005

Frost, R. O., Steketee, G., \& Williams, L. (2000). Compulsive buying, compulsive hoarding, and obsessive-compulsive disorder. Behavior Therapy, 33, 201-214.

Galal, K. A. (2012). The relation between excessive purchase and personality disorders among Minia University employees. Arab Studies in Psychology, 11(1), 99-152.

Hollander, E., \& Allen, A. (2006). Is compulsive buying a Real disorder, and is it Really Compulsive? The American Journal of Psychiatry, 163(10), 1670-1671.

Kellett, S., \& Boltonm J. (2009) compulsive buying: A cognitive-behavioral model. Clinical Psychology and psychotherapy, 16, 83-99. https://doi.org/10.1002/cpp.585

Koran, L. M. Faber, R. J., Aboujaude, E., Large M. D., \& Serape, R. T. (2006). Estimated Prevalence of Compulsive Buying. Behaviorin the United States. The American Journal of Psychiatry, 163(10), 1806-1813. https://doi.org/10.1176/ajp.2006.163.10.1806

Kukar-Kinney, M., Ridgeay, N. M., \& Monroe, K. B. (2012). The role of price in the behavior and purchase decisions of compulsive buyers. Journal of Retailing, 88(1), 63-71. https://doi.org/10.1016/j.jretai.2011.02.004

Kyrios, M., McQueen, P., \& Moulding, R. (2013) Experimental Analysis of the Relationship between Depressed Mood and Compulsive Buying. Journal of Behavior Therapy and Experimental Psychiatry, 44(2), 194-200. https://doi.org/10.1016/j.jbtep.2012.10.004

Lee, S., \& Mysyk, A. (2004). The Medicalization of Compulsive Buying. Social Science \& Medicine, 58, 1718-1970. https://doi.org/10.1016/S0277-9536(03)00340-X

Lejoyeux, M. \& Weinstein. A. (2010). Compulsive buying, The American Journal of Drug and Alcohol Abuse, 36, 248-253. https://doi.org/10.3109/00952990.2010.493590

Liete, P., Range, B., Kukar-Kiney, M. K. Ridgway, N., Monroe, K., Ribas Junior, R.,... Silva, A. (2013). Cross-Cultural Adaptation, Validation and Reliability of the Brazilian Version of the Richmond Compulsive Buying Scale Revista Brasileira de Psiquiatria, 35(1), 38-43 https://doi.org/10.1016/j.rbp.2012.10.004

McElory, S. L., Satlin, A., Pope, H. G., Keck, P. E., \& Hudson, J. (1991). Treatment of compulsive Shopping with Antidepressants: A Report of Three Cases. Annals of Clinical Psychiatry, 13(3), 199-204. https://doi.org/10.3109/10401239109147991 
Moore, M. (2009). Compulsive Shopping Disorder. Is it Real and can it be Measured? PhD thesis. Clinical psychology.North Carolina University. Carolina at Chapel Hill.

Muller, A., Arikian, A., Zwaan, M., \& Mitchell, J. (2011). Cognitive-behavioral group therapy versus guided self-help for CBD: A preliminary study.

Osso, B., Allen, A., Altamura, Buoli, M., \& Hollander, E. (2008). Impulsive-Compulsive buying behavior; Clinical overview. Australian and New Zealand Journal of Psychiatry, 42, 259-266. https://doi.org/10.1080/00048670701881561

Park. T. Y., Cho, S. H., \& Seo, J. (2006). A compulsive buying caste: A qualitative analysis by the grounded theory method. Contempt Fam Ther, 28, 239. https://doi.org/10.1007/s10591-006-9002-2

Pazarlis, P., Katsiginnopoulos, K., Papazisis, G., Bolimou, S., \& Garyfallos, G. (2008). Compulsive Buying. A review. Annals of General Psychiatry, 7(2), 73.

Shanmugam, V. (2011) An empirical examination of antecedents and consequences of $E$-compulsive buying tendencies: The moderating roles of psychological factors. Master of Science. The University of North Carolina at Greensboro.

Wang, Z. (2007). How parent-child relationship affects adolescents compulsive buying behavior through the mediator of self-esteem. Master Degree. Concordia University Canada.

Weaver, S., Moschis, G., \& Davis, T. (2011). Antecedents of materialism and compulsive buying: Life course study in Australia. Australasia Marketing Journal, 19, 247-256. https://doi.org/10.1016/j.ausmj.2011.04.007

Workman, I. (2010). The essential structure of compulsive buying: A Phenomenological Inquiry. Doctor of Philosophy. Utah State University. Logan.

Zahran, H. A. (1980). Guidance and psychological counseling (2nd ed.). Cairo: Alam Alkotob.

\section{Copyrights}

Copyright for this article is retained by the author(s), with first publication rights granted to the journal.

This is an open-access article distributed under the terms and conditions of the Creative Commons Attribution license (http://creativecommons.org/licenses/by/4.0/). 